\title{
Date of earlywood-latewood transition in provenances and families of loblolly pine, and its relationship to growth phenology and juvenile wood specific gravity
}

\author{
K.J.S. Jayawickrama, S.E. McKeand, J.B. Jett, and E.A. Wheeler
}

\begin{abstract}
When grown together in plantations, fast-growing southern and coastal sources of loblolly pine (Pinus taeda L.) often have lower wood specific gravity than northern and inland sources. This study investigated whether this phenomenon could be explained by a later transition to latewood, associated with a longer period of height growth, of the fast-growing sources. Seven to nine open-pollinated families, from each of four provenances, were grown at two locations in southwest Georgia. Tree cambia were wounded with a needle during summer and fall of the fifth and sixth growing seasons (1993 and 1994). The wounding was done to leave a mark in the xylem used later to determine whether earlywood or latewood was being produced at the time of wounding. Provenances were significantly different for the date of transition in 1994, with 22 days between the earliest and the latest. For most families, latewood transition followed height growth cessation in 1993, but preceded it in 1994. The date of latewood transition had a strong positive correlation (family mean basis across provenances) with the date of height growth cessation and a moderate negative correlation with specific gravity. Juvenile wood specific gravity had a weak (nonsignificant) negative correlation with annual height increment and a stronger negative correlation, significant in 1993, with diameter increment. Correlations within provenances were weak or close to zero. This study provided evidence for an association (especially at the provenance level) between a later cessation of height growth, a later transition to latewood, and lower specific gravity in 5- and 6-year-old trees.
\end{abstract}

Résumé : Lorsqu'elles croissent ensemble en plantation, les provenances méridionales et côtières à croissance rapide de pin à encens (Pinus taeda L.) ont fréquemment une densité relative plus faible que les provenances septentrionales et continentales. Cette étude a permis d'examiner si ce phénomène pouvait être expliqué par une transition tardive au bois final, associée à une plus longue période de croissance en hauteur des provenances à croissance rapide. Sept à neuf familles issues de pollinisation libre originant de chacune des quatre provenances étudiées ont été cultivées sur deux emplacements du Sud-Ouest de la Georgie. Le cambium des arbres a été blessé à l'aide d'une aiguille pendant l'été et l'automne des cinquième et sixième saisons de croissance (1993 et 1994). La blessure a été faite afin de laisser une marque dans le xylème qui fut utilisée ultérieurement pour déterminer si du bois initial ou du bois final était produit au moment de la blessure. Les provenances étaient significativement différentes en ce qui concerne la date de transition en 1994, 22 jours séparant la plus hâtive de la plus tardive. Pour la plupart des familles, la transition au bois final a suivi l'arrêt de la croissance en hauteur en 1993, mais l'a précédé en 1994. La date de transition au bois final était fortement corrélée positivement (sur la base des moyennes des familles inter-provenances) avec la date d'arrêt de la croissance en hauteur et modérément corrélée négativement avec la densité relative. La densité relative du bois juvénile a été faiblement corrélée négativement (non significatif) avec l'accroissement annuel en hauteur et plus fortement corrélée négativement, de façon significative en 1993, avec l'accroissement en diamètre. Les corrélations intra-provenances étaient faibles ou presque nulles. Cette étude a fourni la preuve d'une relation (spécialement dans le cas des provenances) entre un arrêt tardif de la croissance en hauteur, une transition tardive au bois final et une densité relative plus faible chez les arbres de 5-6 ans.

[Traduit par la Rédaction]

Received September 5, 1996. Accepted April 11, 1997.

K.J.S. Jayawickrama ${ }^{1}$ and S.E. McKeand. Department of Forestry, North Carolina State University, Raleigh, NC 27695, U.S.A.

J.B. Jett. College of Forest Resources, North Carolina State University, Raleigh, NC 27695, U.S.A.

E.A. Wheeler. Department of Wood Science, North Carolina State University, Raleigh, NC 27695, U.S.A.

1 Author to whom correspondence should be addressed at Genetics and Tree Improvement, New Zealand Forest Research Institute Ltd., Private Bag 3020, Rotorua, New Zealand.

\section{Introduction}

Improving volume production is the main goal of breeding programs for loblolly pine (Pinus taeda L.) in the southern United States. In addition to gains from selecting within local populations, large-volume improvements can be made by using fast-growing nonlocal seed sources. Southern and coastal sources of loblolly pine often grow faster than northern or inland sources, but are more susceptible to cold and drought and have poorer stem form (McKeand et al. 1989).

Most research suggests little or no correlation (at the family level) between growth and specific gravity within populations of loblolly pine (Megraw 1985; Zobel and van Buijtenen 1989; 
Fig. 1. Map of the southeastern United States showing the natural range of loblolly pine (shaded), the four provenances used in the study, and the two study locations.

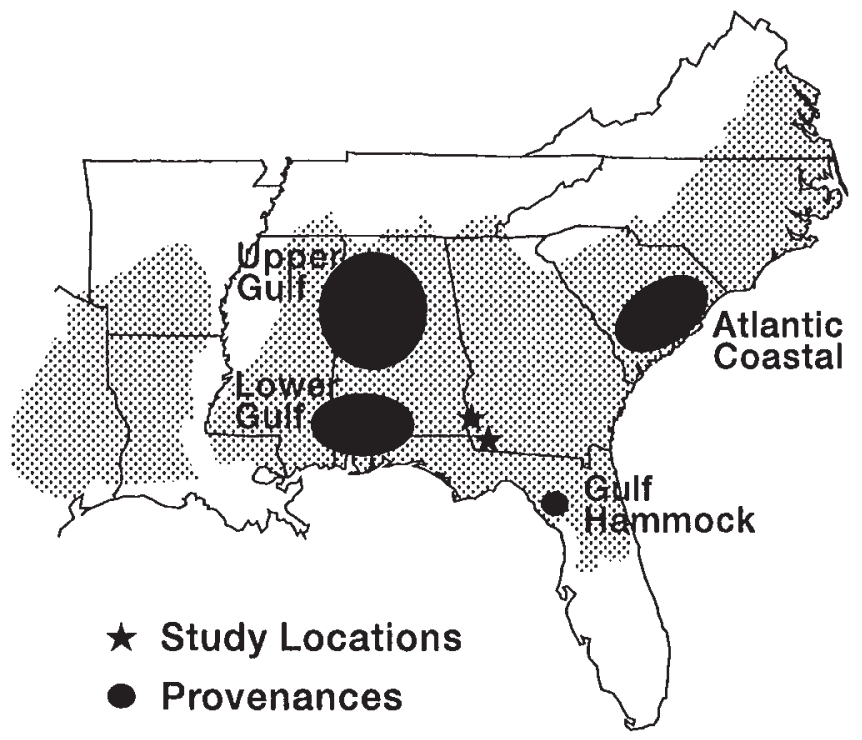

Harding 1995). The situation may be different at the provenance level (Zobel and van Buijtenen 1989; Zobel and Jett 1995). In at least two cases, growth and wood specific gravity appeared to be negatively correlated at the seed source level. In the Western Gulf region, Byram and Lowe (1988) found consistent negative associations (at the seed source level) between growth and specific gravity. A similar relationship was seen for Livingston Parish (south Louisiana) and Florida seed sources in trials throughout the South (Jett et al. 1991). These fast-growing sources had the lowest specific gravities in the series of trials, even though they have the highest specific gravities in their indigenous ranges (Zobel and van Buijtenen 1989).

A negative association between growth rate and wood specific gravity may be related to the phenology of wood formation in loblolly pine and other conifers. Earlywood or springwood is formed in spring and early summer and has low density. Latewood or summerwood is formed in late summer and fall and has high density. The proportion of latewood has a strong impact on wood specific gravity in conifers (van Buijtenen 1964; Gilmore et al. 1966; Zobel and Jett 1995). Thus, slow-growing sources that stop height growth earlier in the season might have denser wood than sources that grow in height longer, if the duration of wood production and tracheid characteristics (e.g., lumen diameter and cell wall thickness) are similar. Southern sources continue height growth later than northern sources (Perry et al. 1966; Worrall 1975; Jayawickrama 1996). The low specific gravity of southern and coastal sources in plantations reported by Byram and Lowe (1988) and Jett et al. (1991) could be due to this phenomenon. Perhaps due to the difficulty of measurement, there have been relatively few studies on variation in the date of latewood transition (Worrall 1970, 1975; Emmingham 1977; Vargas-Hernandez and Adams 1994), especially regarding genetic variation as well as southern pines in general.

This paper reports a study that evaluated the genetic relationships of height growth cessation and diameter growth ces- sation with selected wood properties. These were studied among and within different provenances of loblolly pine at 5 and 6 years of age. The hypothesis was that families or provenances that grow in height later into the season start forming latewood later, leading in turn to lower wood specific gravity at the genotype (provenance or family) level.

\section{Materials and methods}

\section{Study trees}

A study originally planted to verify the effectiveness of early selection (at 1-2 years of age) in different provenances of loblolly pine (McKeand and Bridgwater 1993) was thinned and used for this research. Details of the original study are given in McKeand and Bridgwater (1993) and McKeand and Jett (1993).

The seed sources were five provenances representative of the middle portion of the natural range of loblolly pine. Selections (made in the 1950s and 1960s from wild stands) had been grafted in firstgeneration seed orchards. Open-pollinated seed were collected for this study from these orchards. Thus, both the female parent and the pollen parent came from the designated provenance. Seedlings were raised in containers in Raleigh, N.C., and planted on two locations in southwest Georgia. The plantings, designated GP and IP, respectively, were at Cedar Springs $\left(31^{\circ} 10^{\prime} \mathrm{N}, 85^{\circ} 3^{\prime} \mathrm{W}\right)$ by Georgia-Pacific Corporation and at Bainbridge $\left(30^{\circ} 54^{\prime} \mathrm{N}, 84^{\circ} 36^{\prime} \mathrm{W}\right)$ by International Paper Company. In the spring of 1991 and the summer of 1992, the two plantings were thinned as follows:

(1) Four provenances were retained: Atlantic Coastal Plain (ACP, coastal plain of South Carolina), Gulf Hammock (GH, Levy County, Fla.), Lower Gulf (LG, south Mississippi and south Alabama), and Upper Gulf (UG, north Mississippi and north Alabama).

(2) Eight families were retained in the ACP and GH sources, nine in LG, and seven in UG, giving 32 families in all. The goal was to retain an equal proportion of the tallest and shortest families in each provenance, based on age 2 data.

(3) An average of 10 trees per family was retained per location, maintaining uniform spacing as far as possible. The final density was about 1476 trees/ha at IP and 890 trees/ha at GP. These densities were different due to differences in the original spacing at the two sites and a higher incidence of fusiform rust (Cronartium quercuum (Berk.) Miyabe ex Shirai f.sp. fusiforme) infection at the GP site. The thinning was done to remove diseased trees, remove trees not needed for the study, and relieve spots of extreme overcrowding. Branches below $2 \mathrm{~m}$ were pruned from the study trees to facilitate access. Most of the trees maintained their foliage above the point of pruning, and the crowns were well exposed to sunlight.

The location of the four provenances and two sites is shown in Fig. 1. It should be noted that the parent trees were dispersed through the provenances they represented.

The experimental design in each site was an incomplete block design (18 blocks at GP, 16 at IP) with trees located randomly within a block. There was some imbalance among blocks, with an average 17 trees/block at GP and 21 trees/block at IP. Block size was $147 \mathrm{~m}^{2}$ at GP and $110 \mathrm{~m}^{2}$ at IP.

\section{Growth initiation and cessation}

Height was measured in February 1993 and every 2 weeks from midJune until height growth stopped in late October. In late February 1994 the plantings were visited periodically to observe budbreak and flushing of the trees. Following budbreak, height was measured in May, June, and then every 3 weeks from late July to early October. A height pole was placed near each tree, and the tip of the pole and the terminal bud were observed from a bucket truck. Dendrometer bands were installed in the middle of the first flush of the tree's second growing season (1990). In 1993, band readings were taken at the same 
time as height (beginning in June), and also once each in November and December. In 1994, in addition to occasions when height was measured, weekly dendrometer measurements were taken from July to the end of September, and also once each in October, November, and December.

The purpose of these measurements was to determine the dates of height growth initiation, height growth cessation (defined as the date when a tree completed $95 \%$ of the season's height growth), and diameter growth cessation (95\% of season's growth in 1994, $90 \%$ for 1993). A cutoff point of $90 \%$ was used to diameter growth cessation in 1993, since measurements were started later in the summer.

\section{Latewood formation}

On the same days that diameters were measured, trees were wounded (just below the dendrometer bands) using the cambium wounding technique described by Wolter (1968). Each wound site was marked for future location and identity of measurement date. The wounds were spaced laterally from left to right approximately $3 \mathrm{~cm}$. apart. When minute wounds are made in a radial direction through the vascular cambium, cell division and differentiation are disrupted temporarily at the point of wounding. The cambium later reorganizes and resumes producing orderly radial rows of cells, but the distinctive wound area in the xylem is covered over and will be visible in cross section. It was determined whether earlywood or latewood was being formed at the time of wounding by examining the normal cells near (tangential and adjacent to) the wound.

At the end of 1994 the trees were cut down and a stem section (containing the wounds) was cut from each tree. Small blocks containing the outermost pair of growth rings were sawn out and cut through the wound region. This surface was smoothed with a razor blade and observed using a hand lens. The definition of latewood used in this study was a homogeneous, dark band of wood formed all the way to a well-defined growth ring boundary. This definition excluded false rings, since false rings would be followed (during the same growth ring) first by a light-colored band of earlywood-like cells and then by latewood. The presence of compression wood caused some complications in delimiting latewood. True latewood as defined by Mork (1928) is rarely found in such young trees, but given the aim of comparing genotypes rather than finding absolute percentages of latewood, we felt that applying our criteria consistently to all samples was appropriate. This way of identifying latewood transition was found to be as effective as taking microtome sections and measuring cell dimensions. A typical section with the different regions is shown in Fig. 2.

As the latewood evaluation progressed, the data were periodically analysed. Data collection was halted when results of the hypothesis tests did not change with additional samples. In all, 373 trees were evaluated.

\section{Percent latewood}

The proportion of latewood in the 1994 ring was calculated for the 373 trees in which latewood transition was evaluated. Using the periodic dendrometer band measurements, the radial increment corresponding to earlywood formation (i.e., up to the date when latewood transition was judged to take place) was calculated for each tree. Subsequent radial increment within the growth ring was considered as latewood. Percent latewood was calculated as

Percent latewood $=($ Area of latewood/Area of growth $\mathrm{ring}) \times 100$.

We assumed that the trees had circular cross sections. The 1993 data were not used because diameter measurement was begun in June, and therefore the total radial increment for the season was not known.

\section{Wood specific gravity}

Wedges were cut (avoiding pronounced zones of compression wood) from disks taken from the stem sections described above. The 1993 and 1994 growth rings were split out and unextracted specific gravity measured on an ovendry weight - green volume basis (Zobel and Talbert 1984) using the water displacement technique.

\section{Statistical analyses}

ANOVA

The following statistical model was used:

$$
\begin{aligned}
& \text { Observation }= \text { mean }+ \text { location }+ \text { block }(\text { location })+\text { provenance } \\
&+ \text { family }(\text { provenance })+\text { location } \times \text { provenance } \\
&+ \text { location } \times \text { family }(\text { provenance })+\text { covariate }+ \text { residual }
\end{aligned}
$$

ANOVA was conducted using the GLM procedure in SAS (SAS Institute Inc. 1989). Locations, blocks within locations, and their interactions with other terms were considered random effects. As spacing was uneven, a measure of the amount of space available to each tree was used as a covariate (in an attempt to reduce the effect of uneven spacing). Henceforth called Competition, this measure was the sum of the (diameter at breast height (DBH) $2 /$ distance to tree) for the four nearest neighbors. Larger values for this covariate indicate that the trees were growing under stronger competition. Approximate $F$-tests were obtained using the RANDOM statement in PROC GLM. Since latewood proportions were between 0.2 and 0.7 , the data were not transformed prior to analysis.

\section{Correlations among traits}

Correlation analyses were conducted on least squares means, for families, using PROC CORR in SAS. These were calculated in preference to genetic correlations due to the degree of imbalance in the data, since genetic covariance parameters would be expected to have very large variances.

\section{Regression on latitude}

For the UG and LG sources only, least squares family means were regressed on the approximate latitude of the original selection from the wild using PROC GLM in SAS. Latitude ranges were from $32^{\circ} 40^{\prime} \mathrm{N}$ to $34^{\circ} 45^{\prime} \mathrm{N}$ for $\mathrm{UG}$ and from $31^{\circ} 05^{\prime} \mathrm{N}$ to $32^{\circ} 14^{\prime} \mathrm{N}$ for $\mathrm{LG}$. We felt that this could be of interest because the selections covered a north-south gradient, within a relatively narrow longitudinal region, in Alabama and Mississippi.

\section{Results}

Height and diameter growth cessation results are presented in Jayawickrama (1996), but relevant information is repeated in the discussion here. Provenances were significantly different from each other for the date of latewood transition in 1994, but not for the following: (1) date of latewood transition in 1993, (2) wood specific gravity in either year, and (3) percent latewood in either year (Table 1). There was a range of 22 days in 1994 between the first provenance to undergo transition (UG at 201.5 days) and the last ( $\mathrm{GH}$ at 223.9 days) (Table 2). While the differences between provenances were not significant in 1993 and the range was smaller (14 days), the order in which transition took place was the same as in 1994. Similarly, UG had the highest specific gravity and GH the lowest for both years. Provenance order for percent latewood corresponded exactly to that for specific gravity in the same year (1994), with higher percent latewood being associated with higher specific gravity (Table 2). Percent latewood ranged from $31.5 \%$ for UG to $27.9 \%$ for $\mathrm{GH}$ in 1994 .

There appeared to be differences within provenances in addition to among provenances. Families within provenances were significantly different from each other for date of latewood 
Fig. 2. Surface view through a typical wound obtained by the cambium wounding technique. The following can be seen for the 1993 growth ring: A, latewood; B, location of vascular cambium at time of wounding; C, second false ring; D, first false ring; E, earlywood.

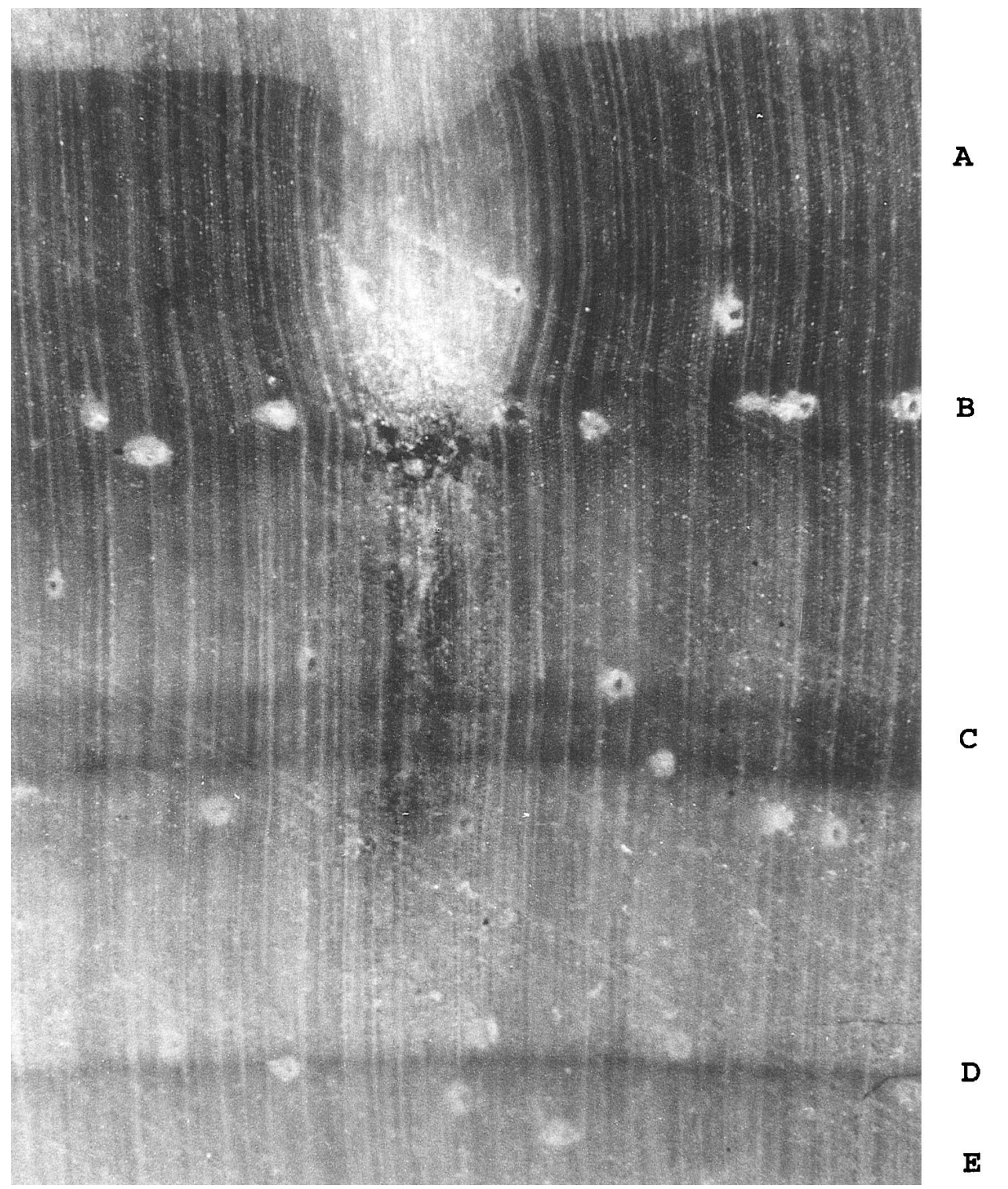

transition and for percent latewood in 1994 and for specific gravity in both years (Table 1).

When family means were considered across provenances, there was a range of 46 days between the earliest and latest transition date in 1994 and of $15.2 \%$ for percent latewood and a difference of 0.074 between the highest and lowest specific gravities.

Correlations among growth and phenology traits with wood property traits ranged from positive to moderately negative, when considered across provenances. Family means for latewood transition date were positively correlated with date of height growth cessation (Table 3; Fig. 3). There were significant negative correlations between specific gravity and date of height growth cessation (Table 3 ) and between latewood transition date and specific gravity (Table 3; Fig. 4). There were nonsignificant negative correlations between height increment and wood specific gravity (Table 3; Fig. 5). Diameter increment was more negatively correlated with specific gravity (Table 3 ).
Correlations within provenances were weaker and less consistent, sometimes varying from positive to nearly zero to negative for the same pair of traits (Table 3). The general lack of relationship within provenances is indicated in Figs. 3-5.

Considering the UG and LG sources, slopes for family means for specific gravity and percent latewood against latitude were positive for both years, indicating higher specific gravity and a higher percentage of latewood for trees of more northern origin. The slopes for latewood transition date were negative for both years, indicating earlier latewood initiation for the more northern trees. Values of $p$ for slope for latewood transition date and specific gravity were less than 0.05 in 1994; all other $p$-values for slope were greater than 0.05 . Values of $R^{2}$ for these regressions did not exceed 0.33 .

In addition to genetic effects, environmental effects appeared to influence the traits measured. Latewood transition took place earlier and specific gravity was higher in 1994 than in 1993 (Table 2). For most families, latewood transition 
Table 1. Analysis of variance for latewood transition date, percent latewood, and wood specific gravity.

\begin{tabular}{|c|c|c|c|c|c|c|}
\hline \multirow[b]{2}{*}{ Source } & \multirow[b]{2}{*}{$\mathrm{df}$} & \multicolumn{2}{|c|}{$\begin{array}{c}\text { Latewood } \\
\text { transition date }\end{array}$} & \multirow{2}{*}{$\begin{array}{c}\begin{array}{c}\text { Percent } \\
\text { latewood }\end{array} \\
1994\end{array}$} & \multicolumn{2}{|c|}{$\begin{array}{l}\text { Wood specific } \\
\text { gravity }\end{array}$} \\
\hline & & 1993 & 1994 & & 1993 & 1994 \\
\hline \multirow[t]{2}{*}{$\mathrm{L}$} & 1 & 11000 & 923.5 & 1743 & 0.0685 & 0.0958 \\
\hline & & $(0.0285)$ & $(0.420)$ & $(0.0214)$ & $(0.0187)$ & $(0.0354)$ \\
\hline \multirow[t]{2}{*}{$\mathrm{B}(\mathrm{L})$} & 18 & 686.9 & 1469.9 & 274 & 0.00117 & 0.00376 \\
\hline & & $(0.0001)$ & $(0.0001)$ & $(0.0001)$ & $(0.711)$ & $(0.0127)$ \\
\hline \multirow[t]{2}{*}{$\mathrm{P}$} & 3 & 2720.1 & 6926.8 & 223 & 0.0110 & 0.0135 \\
\hline & & $(0.2146)$ & $(0.0115)$ & $(0.2139)$ & $(0.069)$ & $(0.3856)$ \\
\hline \multirow[t]{2}{*}{$\mathrm{F}(\mathrm{P})$} & 28 & 119.5 & 688.4 & 100 & 0.00247 & 0.0024 \\
\hline & & $(0.4349)$ & $(0.0477)$ & $(0.0270)$ & $(0.0269)$ & $(0.0073)$ \\
\hline \multirow[t]{2}{*}{$L \cdot P$} & 3 & 1001.4 & 270.6 & 67 & 0.00155 & 0.0089 \\
\hline & & $(0.0001)$ & $(0.531)$ & $(0.2618)$ & $(0.2912)$ & $(0.0001)$ \\
\hline \multirow[t]{2}{*}{$L \cdot F(P)$} & 28 & 112.2 & 362.7 & 48 & 0.0012 & 0.00093 \\
\hline & & $(0.908)$ & $(0.186)$ & $(0.5482)$ & $(0.7690)$ & $(0.987)$ \\
\hline \multirow[t]{2}{*}{ Competition } & 1 & 181.4 & 3561.5 & 36 & 0.00742 & 0.000496 \\
\hline & & $(0.303)$ & $(0.0005)$ & $(0.4004)$ & $(0.0264)$ & $(0.6101)$ \\
\hline Error & 290 & 170.4 & 290.3 & 50 & 0.00149 & 0.00190 \\
\hline$R^{2}$ & & 0.469 & 0.508 & 458 & 0.405 & 0.405 \\
\hline
\end{tabular}

Note: Values given are mean square estimates and the $p$-value for the hypothesis test (in parentheses). Numbers in bold indicate a $p$-value $\leq 0.05$. The covariate Competition is a measure of the space available for each tree. L, location; B, block; P, provenance; F, family.

Table 2. Least squares means for locations and provenances and range of family means for latewood transition date, percent latewood, and wood specific gravity.

\begin{tabular}{|c|c|c|c|c|c|}
\hline & \multicolumn{2}{|c|}{$\begin{array}{c}\text { Latewood } \\
\text { transition date }\end{array}$} & \multirow{2}{*}{$\frac{\begin{array}{c}\text { Percent } \\
\text { latewood }\end{array}}{1994}$} & \multicolumn{2}{|c|}{$\begin{array}{c}\text { Wood specific } \\
\text { gravity }\end{array}$} \\
\hline & 1993 & 1994 & & 1993 & 1994 \\
\hline \multicolumn{6}{|c|}{ Location } \\
\hline GP & 267.4 & 214.0 & 27.5 & 0.392 & 0.445 \\
\hline IP & 255.2 & 210.4 & 32.4 & 0.422 & 0.480 \\
\hline \multicolumn{6}{|c|}{ Provenance } \\
\hline $\mathrm{GH}$ & 268.4 & 223.9 & 27.9 & 0.393 & 0.450 \\
\hline $\mathrm{ACP}$ & 263.1 & 213.6 & 31.0 & 0.404 & 0.470 \\
\hline LG & 258.6 & 209.9 & 29.4 & 0.407 & 0.452 \\
\hline UG & 254.9 & 201.5 & 31.5 & 0.424 & 0.478 \\
\hline \multicolumn{6}{|c|}{ Families within provenances } \\
\hline GH & $265.5-272.2$ & $219.7-227.5$ & $26.2-30.4$ & $0.375-0.410$ & $0.418-0.472$ \\
\hline $\mathrm{ACP}$ & $257.9-270.6$ & $202.9-224.7$ & $27.8-34.6$ & $0.385-0.431$ & $0.457-0.496$ \\
\hline LG & $251.2-262.2$ & $196.0-219.3$ & $27.0-30.5$ & $0.375-0.427$ & $0.429-0.473$ \\
\hline $\mathrm{UG}$ & $248.1-258.3$ & $181.7-212.8$ & $25.6-40.8$ & $0.406-0.449$ & $0.471-0.489$ \\
\hline
\end{tabular}

Note: GH, Gulf Hammock; ACP, Atlantic Coastal Plain; LG, Lower Gulf; UG, Upper Gulf.

followed height growth cessation in 1993 but preceded it in 1994 (Jayawickrama 1996). There were significant differences between the two sites in specific gravity, percent latewood, and date of latewood transition in 1993 (Table 2). Specific gravity was lower, less latewood was formed, and latewood transition took place later at the GP site.

\section{Discussion}

\section{Date of latewood transition}

The cambium wounding method was found to be effective in determining the date of latewood transition in these trees, which were young and widely spaced. The trees grew enough in diameter to identify differences in cambium position between wounds made 1 or 2 weeks apart. This contrasts with
Worrall (1970) who had older trees at a very close spacing and found the technique to be ineffective. For loblolly pine, the method may work best in trees slightly older than those in our study (perhaps 8-10 years old), which would be forming relatively wide growth rings, yet would have better defined latewood zones and less compression wood. One limitation of the wounding technique is its inability to identify the date of transition to a narrower time frame than a week or 10 days.

The differences in latewood transition date that we noted among sources are comparable in magnitude with the maximum difference of about 30 days reported in a study with Douglas-fir (Pseudotsuga menziesii (Mirb). Franco, Emmingham 1977). There was close correspondence in our study between the range among provenance means for the date of latewood transition (Table 2) and for height growth cessation 
Table 3. Correlations among least squares family means for height growth cessation date, latewood transition date, wood specific gravity, percent latewood, annual height increment, and annual diameter increment.

\begin{tabular}{|c|c|c|c|c|c|c|c|}
\hline & \multicolumn{2}{|c|}{$\begin{array}{l}\text { Height growth } \\
\text { cessation with: }\end{array}$} & \multirow{2}{*}{$\begin{array}{c}\text { Latewood } \\
\text { transition } \\
\text { with: } \\
\text { percent } \\
\text { latewood }\end{array}$} & \multicolumn{4}{|c|}{ Specific gravity with: } \\
\hline & $\begin{array}{l}\text { latewood } \\
\text { transition }\end{array}$ & $\begin{array}{l}\text { specific } \\
\text { gravity }\end{array}$ & & $\begin{array}{l}\text { latewood } \\
\text { transition }\end{array}$ & $\begin{array}{c}\text { percent } \\
\text { latewood }\end{array}$ & $\begin{array}{l}\text { height } \\
\text { increment }\end{array}$ & $\begin{array}{l}\text { diameter } \\
\text { increment }\end{array}$ \\
\hline \multicolumn{8}{|c|}{ By year across provenances ${ }^{a}$} \\
\hline 1993 & $\begin{array}{c}0.742 \\
(\mathbf{0 . 0 0 0 1 )}\end{array}$ & $\begin{array}{c}-0.548 \\
(\mathbf{0 . 0 0 1 2})\end{array}$ & & $\begin{array}{c}-0.428 \\
(\mathbf{0 . 0 1 5})\end{array}$ & & $\begin{array}{c}-0.333 \\
(0.062)\end{array}$ & $\begin{array}{c}-0.627 \\
(\mathbf{0 . 0 0 0 1 )}\end{array}$ \\
\hline \multicolumn{8}{|c|}{ By year and provenance ${ }^{b}$} \\
\hline $\begin{array}{l}1993 \\
1994\end{array}$ & \multicolumn{7}{|c|}{ No signficant correlations } \\
\hline GH & $\begin{array}{c}-0.045 \\
(0.913)\end{array}$ & $\begin{array}{c}0.371 \\
(0.366)\end{array}$ & $\begin{array}{c}-0.607 \\
(0.111)\end{array}$ & $\begin{array}{c}-0.359 \\
(0.383)\end{array}$ & $\begin{array}{c}0.378 \\
(0.356)\end{array}$ & $\begin{array}{c}0.132 \\
(0.756)\end{array}$ & $\begin{array}{c}0.127 \\
(0.764)\end{array}$ \\
\hline UG & $\begin{array}{c}0.492 \\
(0.262)\end{array}$ & $\begin{array}{c}0.005 \\
(0.992)\end{array}$ & $\begin{array}{c}0.990 \\
(\mathbf{0 . 0 0 0 1 )}\end{array}$ & $\begin{array}{c}0.328 \\
(0.472)\end{array}$ & $\begin{array}{c}-0.275 \\
(0.551)\end{array}$ & $\begin{array}{c}-0.306 \\
(0.505)\end{array}$ & $\begin{array}{c}-0.202 \\
(0.665)\end{array}$ \\
\hline
\end{tabular}

Note: Values in parentheses are the $p$-values for the hypothesis tests that the correlation coefficient $=0$. Numbers in bold indicate a $p$-value $\leq 0.05$. GH, Gulf Hammock; ACP, Atlantic Coastal Plain; LG, Lower Gulf; UG, Upper Gulf.

${ }^{a} N=32$ families across provenances.

${ }^{b} N=7-9$ families per provenance.

and diameter growth cessation. In each of these three traits the difference between the earliest to undergo transition (UG) and the latest (GH) was about 22 days in 1994. In 1993 the ranges were again comparable for the three traits, being 23.4, 12.1, and 13.5 days for height growth cessation, diameter growth cessation, and latewood transition date, respectively. Trends among provenances were consistent across years, with the order of the four provenances being the same for all three traits for both years. Emmingham (1977) also found a tendency for latewood transition to take place later in southern and coastal sources.

The relatively strong correlation on family means across provenances and weaker correlations within provenances (Table 3) indicated that later height growth cessation was associated with later latewood transition primarily at the seed source level. Latewood transition seemed to occur (at the family mean level) before the trees completed $95 \%$ of the season's height growth. Emmingham (1977) found that latewood transition usually took place in Douglas-fir (at the seed source level) between the date for $90 \%$ shoot extension and $100 \%$ shoot extension. Finally, a simple correlation of 0.61 (on individual trees) between date of height growth cessation and latewood transition date was reported for individual trees of Norway spruce (Picea abies (L.) Karst., Worrall 1970). Together, these studies provide evidence for an association between height growth cessation and latewood transition date at the seed source level and to some extent at the family and individual tree level.

Vargas-Hernandez and Adams (1994) found significant differences among families for the date of latewood transition in Douglas-fir, while Worrall (1970) found a range of 44 days among trees in 1 year for the same trait in Norway spruce.
Fig. 3. Plot of least squares family means for Julian days to height growth cessation versus Julian days to latewood transition for 1994. UG, Upper Gulf; LG, Lower Gulf; ACP, Atlantic Coastal Plain; GH, Gulf Hammock.

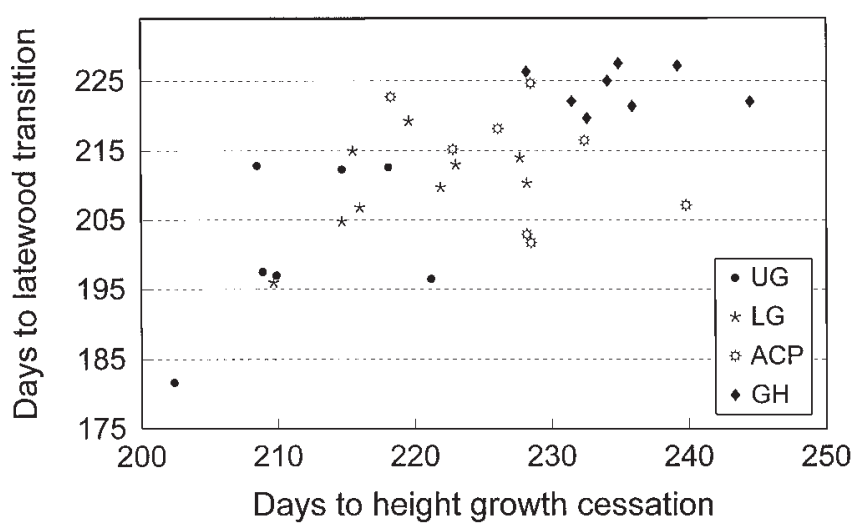

Percent latewood and specific gravity

In our study, percent latewood and specific gravity were similar to the extent of the same provenance rank for both traits. The range of provenance means we observed (27.9-31.5\%) is comparable with the values $(27.5-30.7 \%)$ reported for average whole-core latewood percent in loblolly pine provenances reported by Szymanski and Tauer (1991).

\section{Family mean correlations among traits (across provenances)}

Our data suggested the following correlations: strong, positive for dates of latewood transition and height growth cessation; 
Fig. 4. Plot of least squares family means for wood specific gravity versus Julian days to latewood transition for 1994. UG, Upper Gulf; LG, Lower Gulf; ACP, Atlantic Coastal Plain; GH, Gulf Hammock.

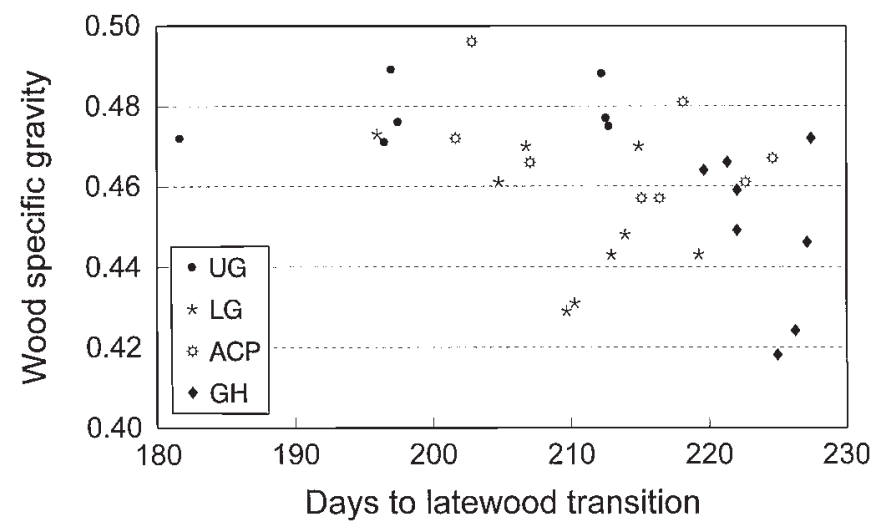

moderate, positive for percent latewood and specific gravity; strong, negative for percent latewood and date of latewood transition; moderate, negative for date of height growth cessation and specific gravity, date of latewood transition and specific gravity, and diameter increment and specific gravity; and weak, negative for height increment and specific gravity.

The negative correlation between latewood transition date and specific gravity is probably due to the latewood proportion having a strong impact on specific gravity in loblolly pine (Gilmore et al. 1966; Zobel and Jett 1995). Thus, families that start latewood formation earlier and produce more latewood are likely to have higher specific gravity. However, our estimation of percent latewood used the latewood transition date in the calculation and this could have inflated the correlation between latewood transition date and percent latewood. Similar to our study, Vargas-Hernandez and Adams (1994) reported a genetic correlation of -0.62 between date of latewood transition and specific gravity in Douglas-fir. The correlation between specific gravity and percent latewood was only moderately strong, with $r=0.43$ (Table 3 ), suggesting the influence of additional traits (such as differences in cell wall thickness and cell lumen size) on specific gravity (Larson 1957; Zobel and van Buijtenen 1989).

Other factors can come into play when trying to understand the interrelationships among factors. First, it has been suggested that in addition to extension growth, needle growth and activity may influence tracheid diameter (Larson 1969). Second, factors that influence stem form may affect the earlywood-latewood transition (Larson 1969), and it is noteworthy that a significantly higher proportion of sinuous stems was observed for the GH source when compared with the UG Source (McKeand and Jett 1993). Third, the formation of latewood or latewood-like cells can be induced by several stimuli (drought, photoperiod, temperature), but the dimensions and wall thickness of cells induced by these stimuli may not be identical (Larson 1969). Different trees, families, and provenances could react differently to environmental stimuli. Given the complexity of the control of latewood formation, the fact that latewood transition date was only partly explained by height growth cessation date, specific gravity only partly explained by the date of latewood transition or the amount of latewood, and height increment only partly explained by the
Fig. 5. Plot of least squares family means for wood specific gravity versus height increment for 1994. UG, Upper Gulf; LG, Lower Gulf; ACP, Atlantic Coastal Plain; GH, Gulf Hammock.

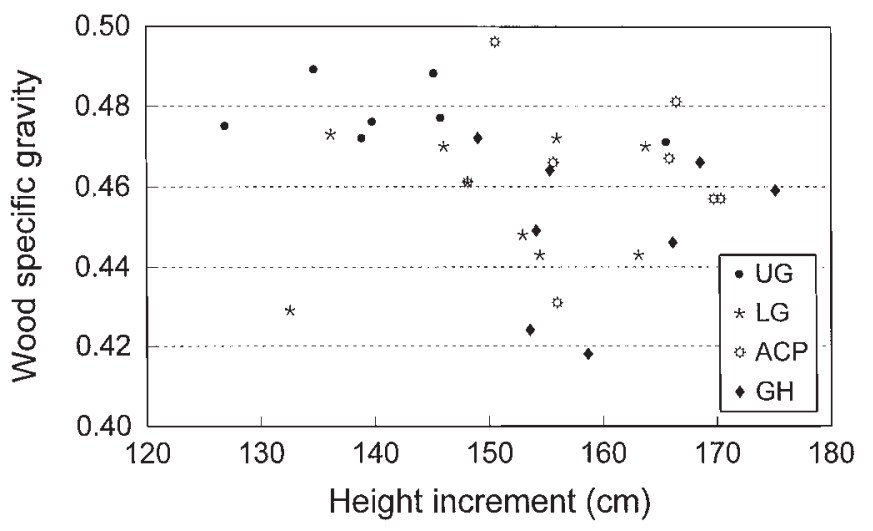

date of height growth cessation, it was not surprising that specific gravity was weakly related to height increment.

While differences among provenances were not significant, the GH source had the lowest specific gravity and UG source the highest in both years. Low specific gravities have been reported for southern sources of loblolly pine in plantations (Byram and Lowe 1988; Jett et al. 1991; Szymanski and Tauer 1991).

\section{Geographic variation in growth rate and wood specific gravity}

The increase of specific gravity that we found from south to north in the LG and UG sources agrees with trends (of different sources planted together in a common environment) reported by Saucier and Taras (1967) and Tauer and Loo-Dinkins (1990). However, latitude only explained part of the variation of the family means, as evidenced by the small $R^{2}$-values.

The differences among provenances in specific gravity (about $5 \%$ in our study) were smaller than those in superior growth in height $(11 \%)$ and diameter $(38 \%)$ of the GH source compared with the UG source. The growth superiority of GH makes this source attractive for establishing plantations even outside its local area, despite its relatively poor form (McKeand and Jett 1993). Comparable studies showed differences between provenances or regions no larger than $12 \%$ for specific gravity but as great as 50\% for volume (Saucier and Taras 1967; Byram and Lowe 1988; Tauer and Loo-Dinkins 1990; Szymanski and Tauer 1991). The ACP source combined very good height growth, good diameter growth, and moderate specific gravity at 5 and 6 years. An earlier measurement of the same study showed the ACP source to have less stem sinuosity than GH (McKeand and Jett 1993).

Weak correlations (within provenances) between growth rate and specific gravity seen in this study and others (Zobel and van Buijtenen 1989) and relatively small differences among and significant differences within provenances for juvenile wood specific gravity indicate that breeders could choose a provenance based on growth rate and adaptability and then choose families within the provenance for the desired specific gravity.

\section{Environmental variables and their effect}

We observed an earlier transition to latewood in 1994 (a wet 
summer) compared with 1993, which had a pronounced dry spell in July and August. Rainfall from June through October in 1994 totaled $1120 \mathrm{~mm}$ in contrast with $470 \mathrm{~mm}$ in 1993 (Jayawickrama 1996). The higher specific gravity that we observed in 1994 compared with 1993 was probably related to the earlier transition to latewood. Cregg et al. (1988) found a greater proportion of latewood in a wet year compared with a dry year, and planting locations with the highest summer rainfall produced the highest specific gravity in another study (Byram and Lowe 1988). Percent latewood was found to be strongly correlated (positively) with June-July rainfall in slash pine (Larson 1957). Finally the trees were a year older in 1994, and it is well known that percent latewood and specific gravity increase steadily during the first years of pine tree growth (Larson 1957; Zobel and van Buijtenen 1989; Harding 1995).

Other differences that we observed between the two years were the presence of one or more distinct false rings in 1993 (mostly absent in 1994), a more gradual earlywood-latewood transition in 1994, the presence of significant differences among provenances for latewood transition date in 1994 (but not in 1993), and the relationship between dates of height growth cessation and latewood transition (height growth cessation taking place first in 1993 and second in 1994). The false ring in 1993 appeared to be related to a dry spell in midsummer followed by more favorable growing conditions. In contrast, there was frequent rain from June through October in 1994, apparently providing the study trees enough moisture to continue growth through the summer.

The lack of significant differences among provenances in 1993 was nonetheless accompanied by the same order of latewood transition in 1993 as in 1994. Thus, it appeared that the trends were the same in both years, but environmental conditions did not allow as much expression of the genetic differences among sources in 1993 as in 1994 (a range of only 14 days rather than 22 days). This was perhaps also seen in the significant differences among families (within provenances) for this trait in 1994 but not in 1993, with a larger range among family means in 1994.

The differences between the two sites in specific gravity, percent latewood, and date of latewood transition in 1993 (Table 2) may be partly due to differences in spacing, which was denser at the IP site: latewood transition may take place later at higher density (Cregg et al. 1988). In addition to different spacing, site conditions that promote faster growth may lead to lower wood density (Belonger et al. 1996). In our study, diameter increment for the two years was $40 \%$ more at the GP site than at the IP site (although height increment was $13 \%$ less), and specific gravity about $8 \%$ lower.

\section{Expected trends with increasing age}

The trends observed in our study could change when trees are closer to rotation age, since many wood properties change with the transition from juvenile to mature wood (Zobel and van Buijtenen 1989). The proportion of latewood increases as trees grow older (Larson 1957, 1969), as does specific gravity. While specific gravity would increase in all the sources and families, rank changes are likely to be small given the strong family-level (Williams and Megraw 1994; Harding 1995; Zobel and Jett 1995), seed-source-level (Szymanski and Tauer 1991), and region-level (Talbert and Jett 1981) juvenile-mature correlations reported for specific gravity in loblolly pine.

\section{Conclusions}

Differences in the date of latewood transition at the provenance level explained differences in percent latewood and specific gravity in young trees of loblolly pine, with an earlier transition to latewood associated with higher percent latewood and higher specific gravity. The hypothesis of a later date of height growth cessation being associated with later transition to latewood was accepted with respect to provenances but not for families. While provenances that grew faster in height and diameter tended to have lower specific gravity, their relative superiority in growth rate was greater than the reduction in specific gravity. Significant differences in specific gravity within provenances suggested that selection of suitable provenances for growth rate and adaptability could be combined with selection within provenances for specific gravity.

\section{Acknowledgements}

This work was funded by a grant from Georgia-Pacific Corporation, an assistantship given to K.J.S.K. by the Department of Forestry, North Carolina State University, and support from the North Carolina Agricultural Research Service. GeorgiaPacific Corporation and International Paper Company each planted, maintained, and harvested one of the sites. We thank Bruce Zobel for suggestions in the development of the study and comments on this manuscript, Tony LaPasha for help with photography and in developing the technique used in evaluating latewood transition, and Jean Pittman for data entry work. Kevin Harding, Chris Hunt, Judith Jayawickrama, and Paula Zanker helped in the field measurements. Journal referees of an earlier version of the paper made useful suggestions for improvement.

\section{References}

Belonger, P.J., McKeand, S.E., and Jett, J.B. 1996. Genetic and environmental effects on biomass production and wood density in loblolly pine. In Tree improvement for sustainable tropical forestry. Edited by M.J. Dieters, A.C. Matheson, D.G. Nikles, C.E. Harwood, and S.M. Walker. Proc. QFRI-IUFRO Conference, Oct. 27 Nov. 1, 1996, Caloundra, Queensland, Australia. pp. 307-310.

Byram, T.D., and Lowe, W.J. 1988. Specific gravity variation in a loblolly pine seed source study in the western gulf region. For. Sci. 34: 798-803.

Cregg, B.M., Dougherty, P.M., and Hennessey, T.C. 1988. Growth and wood quality of young loblolly pine trees in relation to stand density and climatic factors. Can. J. For. Res. 18: 851-858.

Emmingham, W.H. 1977. Comparison of selected Douglas-fir seed sources for cambial and leader growth patterns in four western Oregon environments. Can. J. For. Res. 7: 154-164.

Gilmore, A.R., Boyce, S.G., and Ryker, R.A. 1966. The relationship of specific gravity of loblolly pine to environmental factors in southern Illinois. For. Sci. 12: 399-405.

Harding, K.J. 1995. Age trends of genetic parameters for wood properties of loblolly pine. Ph.D. thesis, North Carolina State University, Raleigh, N.C.

Jayawickrama, K.J.S. 1996. Date of earlywood-latewood transition in provenances and families of loblolly pine, and its relationship to growth phenology and juvenile wood specific gravity. Ph.D. thesis, North Carolina State University, Raleigh, N.C.

Jett, J.B., McKeand, S.E., and Weir, R.J. 1991. Stability of juvenile wood specific gravity of loblolly pine in diverse geographic areas. Can. J. For. Res. 21: 1080-1085. 
Larson, P.R. 1957. Effect of environment on the percentage of summerwood and specific gravity of slash pine. Bull. No. 63, Yale University School of Forestry, New Haven, Conn.

Larson, P.R. 1969. Wood formation and the concept of wood quality. Bull. No. 74, Yale University School of Forestry, New Haven, Conn.

McKeand, S.E., and Bridgwater, F. 1993. Provenance and family variation for juvenile growth characteristics of Pinus taeda L. and the impact for early selection for growth. Stud. For. Suec. 191: $5-10$.

McKeand, S.E., and Jett, J.B. 1993. Growth and stem sinuosity of diverse provenances of three-year-old loblolly pine. In Proceedings of the 22nd Southern Forest Tree Improvement Conference, June 14-17, 1993, Atlanta, Ga. pp. 208-213.

McKeand, S.E., Weir, R.J., and Hatcher, A.V. 1989. Performance of diverse provenances of loblolly pine throughout the southeastern United States. South. J. Appl. For. 13: 46-51.

Megraw, R.A. 1985. Wood quality factors in loblolly pine. Technical Association of the Pulp and Paper Industry Press, Norcross, Ga.

Mork, E. 1928. Die Qualität des Fichtenholzes unter besonderer Rücksichtnahme auf Schliefund Papierholz. Papier Fabrikant, 26: 741-747.

Perry, T.O., Chi-Wu, W., and Schmitt, D. 1966. Height growth for loblolly pine provenances in relation to photoperiod and growing season. Silvae Genet. 15: 61-64.

SAS Institute Inc. 1989. SAS/STAT user's guide, version 6, edition 4. SAS Institute Inc., Cary, N.C.

Saucier, J.R., and Taras, M.A. 1967. Wood density and percent summerwood variation among nine loblolly pine seed sources grown in Alabama. In Proceedings of the 9th Southern Conference on Forest Tree Improvement, June 8-9, 1967, Knoxville, Tenn. Eastern Tree Seed Laboratory, USDA Forest Service, Macon, Ga. pp. 115-119.
Szymanski, M.B., and Tauer, C.G. 1991. Loblolly pine provenance variation in age of transition from juvenile to mature wood specific gravity. For. Sci. 37: 160-174.

Talbert, J.T., and Jett, J.B. 1981. Regional specific gravity values for plantation grown loblolly pine in the southeastern United States. For. Sci. 27: 801-807.

Tauer, C.G., and Loo-Dinkins, J.A. 1990. Seed source variation in specific gravity of loblolly pine grown in a common environment in Arkansas. For. Sci. 36: 1133-1145.

van Buijtenen, J.P. 1964. Anatomical factors influencing wood specific gravity of slash pines and the implications for the development of high-quality pulpwood. TAPPI (Tech. Assoc. Pulp Pap. Ind.), 47: 401-404.

Vargas-Hernandez, J., and Adams, W.T. 1994. Genetic relationships between wood density components and cambial growth rhythm in young coastal Douglas-fir. Can. J. For. Res. 24: 1871-1876.

Williams, C.G., and Megraw, R.A. 1994. Juvenile-mature relationships for wood density in Pinus taeda. Can. J. For. Res. 24: 714-722.

Wolter, K. 1968. A new method for marking xylem growth. For. Sci. 14: $102-104$.

Worrall, J. 1970. Interrelationships among some phenological and wood property variables in Norway spruce. TAPPI (Tech. Assoc. Pulp Pap. Ind.), 53: 58-63.

Worrall, J. 1975. Provenance and clonal variation in phenology and wood properties of Norway spruce. Silvae Genet. 24: 2-5.

Zobel, B.J., and Jett, J.B. 1995. Genetics of wood production. SpringerVerlag, Berlin.

Zobel, B.J., and Talbert, J. 1984. Applied tree improvement. John Wiley \& Sons, New York.

Zobel, B.J., and van Buijtenen, J.P. 1989. Wood variation, its causes and control. Springer-Verlag, Berlin. 